\title{
Роль бухгалтерского учета в обеспечении экономической безопасности организации
}

\author{
Галина Яричина, Ольга Ситяева*, Олеся Антонова, Алена Скуратова
}

Сибирский Федеральный университет, г. Красноярск, Россия

Информашия о статье

Поступила в редакичю:

25.05.2019

Принята

к опубликованию:

24.09.2019

Удк 338

JEL M41

\section{Ключевые слова:}

экономическая безопасность организации, бухгалтерский учет, бухгалтерские риски, учетная политика, внутренний контроль

\section{Keywords:}

economic security of the entity, accounting, accounting risks, accounting policy, internal control

\begin{abstract}
Анноташия
Состояние экономической безопасности организации является важной качественной характеристикой ее функиионирования и развития. На сегодняшний день существует значительное количество научных исследований, посвященных этому вопросу, однако роль бухгалтерского учета в обеспечении экономической безопасности организаџии освещена недостаточно полно.

Целью данного исследования является выявление значения бухгалтерского учета в обеспечении экономической безопасности организаиии. Предмет исследования - экономическая безопасность организации. В статье рассмотрень методы бухгалтерского учета по обеспечению экономической безопасности, определены функиии бухгалтерского учета, через которые осуществляется регулирование деятельности организации, представлена классификация бухгалтерских ошибок и рисков, негативно влияющих на ее экономическую безопасность. В качестве примера влияния бухгалтерского учета на экономическую безопасность рассмотрена деятельность реальных организаций.
\end{abstract}

The Role of Accounting in Ensuring the Economic Security of the Entity

Galina Yarichina, Olga Sityaeva, Olesya Antonova,

Alena Skuratova

\section{Abstract}

For the sustainable development of the organization it is necessary to ensure its economic security, which largely depends on the correct and reliable accounting. This article has revealed the role of accounting in ensuring the economic security of the organization. The study also analyzed the methods of accounting, its functions, which determine the direction of regulation of the organization.

In addition, the article identified factors that reduce the reliabilit of financial statements, proposed measures to minimize these fac tors. Apart from eliciting the negative impact factors, the ways c eliminating them have been offered; the structure of judicial er. forcement has also been in focus. The main findings may be sur marized as follows: payouts on claims under court decisions

\footnotetext{
* Автор для связи: sityaeva.olga@mail.ru DOI: https://dx.doi.org/10.24866/2311-2271/2019-3/183-188
} 
prevail over such not based on court decisions and motor insurance is of great significance for the economic and financial security of the Russian Federation.

Организация, являясь открытой системой, в процессе своей деятельности постоянно взаимодействует, как с внешней средой через различные отношения с государством, юридическими и физическими лицами, так и внутренними структурными подразделениями. В процессе этих взаимодействий возникают различные внешние и внутренние угрозы, которые способны дестабилизировать деятельность организации. Экономическая безопасность - это такое состояние хозяйствующего субъекта, при котором он, наиболее эффективно используя корпоративные ресурсы, предотвращает угрозы и обеспечивает достижение целей бизнеса в условиях конкуренции и хозяйственного риска [1].

Обеспечение экономической безопасности - необходимое условие стабильности и эффективности деятельности организации. В современных условиях недобросовестной конкуренции, коррупции, теневой экономики актуальность ее обеспечения возрастает. Для наиболее эффективного обеспечения экономической безопасности организации используется комплекс мер организационной, профилактической и управленческой направленности, реализующих ее защиту от разного рода угроз.

Составной частью системы экономической безопасности являются средства, при помощи которых осуществляется ее реализация. Одним из таких средств является бухгалтерско-статистическая оценка экономической безопасности хозяйствующих субъектов, включающая элементы внешнего и внутреннего контроля и анализа. Данный метод обеспечения устойчивости организации используется при прогнозировании и нейтрализации различного рода угроз, обусловленных рисками, а также для осуществления грамотного управления. При проведении более полной и глубокой оценки экономической безопасности особое внимание следует уделить такому элементу системы управления организацией, как ее учетная политика. Согласно федеральному закону «О бухгалтерском учете» от 06.12.2011 №402-Ф3 [2] под учетной политикой понимается совокупность способов ведения экономическим субъектом бухгалтерского учета. Учетная политика самостоятельно формируется организацией в зависимости от особенностей ее деятельности и структуры. Именно способы ведения бухгалтерского дела позволяют наиболее эффективно осуществлять регулирование деятельности организации через выполнение следующих функций бухгалтерского учета: информационной, контрольной, правовой регламентации, регулирующей, прогностической [3].

Информационная функция. Формируя объективную, достоверную и оперативную информацию о хозяйствующем субъекте, бухгалтерский учёт позволяет обеспечить пользователей данными о реальном состоянии финансовой и хозяйственной деятельности организации.

Функция правовой регламентации состоит в фиксировании каждого шага хозяйственной деятельности организации при помощи необходимых для конкретной ситуации первичных документов. Осуществляя правовую регламентацию в соответствии с законодательно-нормативной базой, бухгалтерский учет позволяет организации наиболее полно упорядочить деятельность всех своих структурных элементов.

Регулирующая функция помогает осуществлять корректировку деятельности организации в течение всего учетного процесса. 
Прогностическая функция позволяет отыскать оптимальный путь регулирования деятельности организации, то есть такой вариант управления, который бы позволил определить наиболее приоритетные направления развития организации в будущем.

Контрольная функция позволяет, обеспечивая рациональность и законность использованных источников, осуществлять надзор над деятельностью организации и производить ее корректировку. В ходе реализации данной функции, возникает потребность в осуществлении внутреннего контроля со стороны хозяйствующего субъекта, обусловленная необходимостью повышения эффективности функционирования организации. Внутренний контроль рассматривается как процесс, направленный на получение достаточной уверенности в том, что экономический субъект обеспечивает:

- осуществление эффективной и результативной деятельности;

- обеспечение достоверности и своевременности формирования и опубликования бухгалтерской и иной отчетности;

- соблюдение законодательства, в особенности в сфере, касающейся ведения бухгалтерского учета и осуществления фактов хозяйственной жизни [4].

Отсюда следует, что звено управления должно создавать и организовывать систему внутреннего контроля таким образом, чтобы это позволило сократить воздействие угроз и злоупотреблений, искажающих данные бухгалтерского учета в корыстных целях.

Бухгалтерская отчетность призвана давать достоверное представление о финансовом положении организации. Но в ходе осуществления бухгалтерского учета возникают различные ошибки, искажающие бухгалтерскую отчетность. В связи с этим выделяют следующие бухгалтерские ошибки, которые организация должно нейтрализовать в целях обеспечения экономической безопасности:

1) процедурные ошибки (возникают при неправильном оформлении бухгалтерской отчетности):

- ошибки в дате отражения хозяйственной операции;

- отсутствие первичных документов;

- ошибочное составление корреспонденции счетов;

- неотражение или неполное отражение резервов в бухгалтерской отчетности;

- некорректное отражение задолженностей и обязательств.

2) технологические ошибки (возникают при использовании устаревших программ бухгалтерского учета, сбоях в работе компьютера):

- неверное отражение показателей бухгалтерской отчетности;

- ошибки в оценке активов и обязательств;

- неверное отражение информации в отчетных формах.

Из судебной практики можно сделать вывод, что доля правонарушений, в основе которых лежат бухгалтерские ошибки, составляет $2 \%$ от общего числа судебных дел [5].

Также обеспечение полноты и достоверности информации, отражаемой в отчетности невозможно без выявления и оценки бухгалтерских рисков. А. Е. Шевелев под бухгалтерским риском понимал риски, связанные с утратой и искажением информации, что приводит к непредсказуемым потерям [6]. Бухгалтерский риск возникает при неправильном ведении бухгалтерского учета и отчетности, наличии в ней неопределенности. В связи с этим, можно выделить 
следующие источники угроз экономической безопасности, обусловленных системой бухгалтерского учета:

- несоответствие деятельности организации законодательству РФ;

- система регулирования бухгалтерского учета;

- качество бухгалтерской информации;

- персонал бухгалтерской службы.

По классификации А. Е. Шевелева различают следующие основные виды бухгалтерских рисков:

- рыночный риск (риск, приводящий к изменению стоимости активов организации в результате динамики рыночных факторов);

- кредитный риск (риск, связанный с возможностью неисполнения заемщиком своих обязательств);

- операционный риск (риск, возникающий вследствие некорректного выполнения организацией бизнес-функций, приводящего к возникновению издержек).

Бухгалтерские риски негативно влияют на деятельность организации и могут приводить к таким последствиям как снижение качества финансовой отчетности, фальсификация показателей отчетности, ухудшение деловой репутации организации, сокращение величины активов. Таким образом, организации для обеспечения экономической безопасности следует создать условия, при которых бухгалтерские риски не приводили бы к возможности ее ликвидации.

Одним из бухгалтерских методов по нейтрализации рисков является создание и использование отдельных резервов, которые вправе создать коммерческая организация. В бухгалтерском учете организации предусмотрена возможность создания резервов под снижение стоимости материальных ценностей, под обесценение вложений в ценные бумаги, по сомнительным долгам, предстоящим расходам. Кодекс об административных правонарушениях предусматривает ответственность руководителя или главного бухгалтера за искажение статьи бухгалтерской отчетности не менее чем на 10 процентов вследствие неверного начисления резервов.

Можно выделить также следующие меры, минимизирующие бухгалтерские риски:

- совершенствование управленческих решений по учету рисков;

- регулярное отслеживание изменений в рыночной конъюнктуре, законодательстве;

- тщательная проверка договоров с партнерами на предмет соответствия налоговому и бухгалтерскому законодательству.

Снижать бухгалтерские риски позволяет и эффективная организация бухгалтерского учета, особенности которой отражаются в учетной политике фирмы. Не стоит забывать о том, что ПБУ 1/2008 «Учетная политика организации» предусматривает возможность упрощенного ведения бухгалтерского учета микропредприятиями и некоммерческими организациями (без обязательного использования двойной записи). Меры, предусмотренные законодателем, позволяя рационально управлять организацией, в свою очередь, несут угрозу ее экономической безопасности. Организация самостоятельно принимает решение об использовании элементов бухгалтерского учета, о содержании учетной политики, что приводит к усложнению внутреннего контроля [7]. 
Обеспечить устойчивость хозяйствующего субъекта призвана инвентаризация имущества, обязательств, документов бухгалтерского учета, позволяющая выявить ошибки, искажения, недостоверное отображение фактов хозяйственной жизни организации.

Важным экономическим ресурсом организации является бухгалтерский персонал, от квалификации которого зависит достоверность бухгалтерского учета и отчетности. Следовательно, экономическая безопасность организации обеспечивается постоянным повышением квалификации бухгалтерских кадров. Немалую роль при обеспечении экономической безопасности организации оказывает и система мотивации персонала бухгалтерии, эффективность которой настраивает работников на добросовестное выполнение своих трудовых функций.

В реальной жизни существуют большое количество примеров действий руководителей и бухгалтеров, направленных на удовлетворение собственных корыстных интересов, которые разрушают экономическую безопасность организации. Так, директор и главный бухгалтер ОАО «АРЗИЛ», позже осужденные по ст. 199 п.2 Уголовного кодекса РФ, осуществляли планомерное сокрытие денежных средств путем искажения финансовой отчетности, что в дальнейшем поспособствовало снижению эффективности деятельности акционерного общества и смене руководства. Широкую огласку в местных СМИ получило дело об отзыве лицензии у московского банка «Тандем». Немаловажным фактом, способствовавшим осуществлению данного решения Центрального Банка, явилось обвинение главного бухгалтера «Тандема» в совершении фальсификации документов бухгалтерского учета и отчетности финансовой организации. Согласно постановлению Пресненского районного суда Москвы от 17 декабря 2017 года, главный бухгалтер ООО «Банк «Тандем» был осужден за внесение в отчетную документацию кредитной организации заведомо недостоверной информации.

Обеспечение необходимого контроля над соблюдением бухгалтерского и налогового законодательства, формирование полной и качественной учетной информации и отчетности позволят предотвратить возможные риски и угрозы деятельности организации и более рационально использовать ее потенциал для обеспечения экономической безопасности и дальнейшего развития.

\section{Список источников / References}

1. Гапоненко В. Ф., Беспалько А. Л., Власков А. С. Экономическая безопасность предприятий. Подходы и принципы. Москва, «Ось-89», 2014. 208c. [Gaponenko V. F., Bespal'ko A. L., Vlaskov A. S. Ekonomicheskaya bezopasnost' predpriyatij. Podhody i principy [Economic security of enterprises. Approaches and principles]. Moscow, OS-89, 2014. 208p.]

2. Федеральный закон «О бухгалтерском учете» от 06.12.2011 г. №402-Ф3 [Federal law "On accounting" from 06/12/2011 No. 402-FZ] Available at: http://www.consultant.ru

3. Косарев С. Ю., Павлюков Е. В. Правовые и бухгалтерско-статистические методы оценки экономической безопасности хозяйствующего субъекта. Вестник СанктПетербургской юридической академии, 2012, №4(17), сc. 77-83. [Kosarev S. YU., Pavlyukov E. V. Pravovye i buhgaltersko-statisticheskie metody ocenki ekonomicheskoj bezopasnosti hozyajstvuyushchego sub"ekta [Legal, accounting and statistical methods for estimating the economic security of an economic entity]. Vestnik Sankt-Peterburgskoj 
yuridicheskoj akademii. 2012 [Bulletin of St. Petersburg law Academy. 2012]. 2012, pp. 77-83.]

4. Информация Министерства финансов Российской Федерации № ПЗ-11/2013 «Организация и осуществление экономическим субъектом внутреннего контроля совершаемых фактов хозяйственной жизни, ведения бухгалтерского учета и составления бухгалтерской (финансовой) отчетности» [Information of Ministry of Finance of the Russian Federation No. PZ-11/2013 «Organization and implementation of internal control committed facts of economic life, accounting and preparation of accounting (financial) statements by economic entity»] Available at: http://www.consultant.ru

5. Раздел судебная практика. Консультант Плюс [Section of judicial practice. Consultant plus] Available at: http://www.consultant.ru

6. Шевелев А. Е., Шевелева Е. В. Риски в бухгалтерском учете. Москва, КНОРУС, 2015. 304c. [SHevelev A. E., SHeveleva E. V. Riski v buhgalterskom uchete [Risks in accounting]. Moscow, KNORUS, 2015. 304p.]

7. Положение по бухгалтерскому учету ПБУ 1/2008 «Учетная политика организации» [Regulation on accounting PBU 1/2008 "Accounting policy of the organization"] Available at: http://www.consultant.ru

\section{Сведения об авторах / About authors}

Яричина Галина Федоровна, кандидат экономических наук, доцент, доцент кафедры «Экономика и управление бизнес-процессами», Сибирский федеральный университет. 660041 г. Красноярск, пр. Свободный,79. E-mail: sanya080407@yandex.ru

Galina F. Yarichina, Candidate of Economics Sciences, Associate Professor, Associate Professor of the Department of Economics and Management of Business Processes, Siberian Federal University. 660041 Krasnoyarsk, pr. Svobodny, 79. E-mail: sanya080407@yandex.ru

Ситяева Ольга Сергеевна, студент, Сибирский федеральный университет. 660041 г. Красноярск, пр. Свободный,79. E-mail: sityaeva.olga@mail.ru

Olga S. Sityaeva, Student, Siberian Federal University. 660041 Krasnoyarsk, pr. Svobodny, 79.

E-mail: sityaeva.olga@mail.ru

Антонова Олеся Александровна, студент, Сибирский федеральный университет. 660041 г. Красноярск, пр. Свободный,79.E-mail: antonoles@yandex.ru

Olesya.A. Antonova, Student, Siberian Federal University. 660041 Krasnoyarsk, pr. Svobodny, 79.

E-mail: antonoles@yandex.ru

Скуратова Алена Александровна, студент, Сибирский федеральный университет. 660041 г. Красноярск, пр. Свободный,79. E-mail: skuratovaal@mail.ru

Alena A. Skuratova, Student, Siberian Federal University. 660041 Krasnoyarsk, pr. Svobodny, 79.

E-mail: skuratovaal@mail.ru 